\title{
Effect of Phytoestrogen (Fennel) on Some Sex Hormones and Other Physiological Parameters in Male Albino Rats \\ Eman G.E. Helal ${ }^{1}$, Nora Abdul-Aziz AL Jalaud ${ }^{2}$, Mohamed A. El-Aleem ${ }^{3}$, Shaimaa S. Ahmed ${ }^{1}$
}

Zoology Department, Faculty of Science, Al-Azhar University (Girls), Cairo, Egypt ${ }^{1}$, Imam Abdulrahman Bin Faisal University ${ }^{2}$, Physiology Department, Faculty of Medicine, Al-Azhar University (Boys), Cairo, Egypt ${ }^{3}$

*Corresponding Author: Eman G.E. Helal, E-mail: emanhelal@ hotmail.com, mobile: 00201001025364,

Orchid.org/0000-0003-0527-7028

\begin{abstract}
Background: Phytoesrogenis plant derived compounds which have an estrogenic effect.

Objectives: The present study was carried out to investigate some pharmacological and biochemical effects of fennel oil on male albino rats.

Materials and methods: Twelve animals were divided randomly into two groups. Group A: Control.

Group B: Treated rats. The rats were given an oral dose of $1 \mathrm{ml} / \mathrm{kg}$ body weight/day fennel oil once daily for one month. At the end of the experiment, blood samples were collected for biochemical analysis.

Results: The fennel oil induced highly significant decrease $(\mathrm{p}<0.01)$ in total cholesterol(TC), triglycerides $(\mathrm{TG})$, low-density lipoprotein (LDL), very low-density lipoprotein (VLDL), LDL/high-density lipoprotein (HDL), while significant increased $(\mathrm{p}<0.05)$ HDL. In addition, it showed highly significant decrease $(\mathrm{p}<0.02)$ in FSH, testosterone and sperm count compared to normal control group.

Conclusion: Fennel herb has several therapeutic benefits, but it also has negative effect on male sex hormone and sperm count. So men must reduce their usage of it.
\end{abstract}

Keywords: Fennel, Lipid profile, Albino rats, Physiological parameters.

\section{INTRODUCTION}

Fennel (Foeniculumvulgare) is a well-known Mediterranean aromatic plant. It is a herb consumed orally and having several therapeutic applications. Besides,it is used in traditional medicine and as a spice. It has diuretic, analgesic, antipyretic, and antioxidant activity ${ }^{(1)}$.

Its therapeutic properties are due to volatile compounds; phenols, and flavonoids in the plant extract. According to phytochemical studies, over 30 various terpenes and terpenoids have been identified in fennel ${ }^{(2)}$.

Moreover, other compounds such as estragole (methyl chavicol), fenchone, trans-anethole, and $\alpha$ phellandrene are the main constituents of the fennel seed $^{(3)}$.

The presence of flavonoids, cumarin, and anethole has been also identified. Anethole and fenchone are the main components ${ }^{(4,5)}$. Cumarin has anti-aromatase, estrogenic, reductase inhibiting, and anti-androgen activities. Moreover, flavonoids and anethole are also estrogenic compounds that could depress serum levels of testosterone, and as a result, reduce sperm production ${ }^{(6)}$.
In the present study, we aim to clarify the effect of fennel as phytoestrogen on some sexual hormone and some physiological parameters in male albino rats.

\section{MATERIALS AND METHODS}

Fennel oil was purchased from Cap Pharm for Extracting Natural Oils \& Herbs, Cairo, Egypt. The oil of fennel contains $50 \%$ of trans-anethole and $25 \%$ of fenchone.

\section{Experimental animals}

The experiment was carried out on 12 male albino rats of the Rattus rattus strain weighting (130$140 \mathrm{gm}$ ) obtained from animal farm of El-Nile Company for Pharmaceutical Product (El-Nile, Cairo, Egypt). Animals were housed in metallic cages and maintained under standard condition of temperature, humidity and natural light/dark cycle along the experimental period.

Food and water were available throughout the experiment ad libitum.

Rats were left to acclimatize for one week before starting the experiment. 
Effect of Phytoestrogen (Fennel) on Some Sex Hormones...

\section{Experimental design}

In current study, 12 male Albino rats were divided into two equal groups (6 rats in each group) as the following:

Group I: (control group): comprised of normal rats and maintained on standard pellet diet and tap water ad libitum for 30 days.

Group II: rats received orally fennel seed oil $(1 \mathrm{ml} / \mathrm{kg}$ body weight) for 30 days.

\section{Body weight measurement}

Body weight was recorded before and after the experiment.

\section{Blood sample collection}

At the end of the experimental period, the blood samples were collected from the retro-orbital sinus of anesthetized rats (by ether) after overnight fasting. Serum was separated by centrifugation at $2500 \mathrm{~g}$ for 15 minutes at room temperature to estimate biochemical parameters.

\section{Biochemical analysis}

\section{Assessment of biochemical parameters:}

In the present study, total protein (TP) and albumin concentration were estimated, then serum globulin concentrations were calculated according to the formula: Globulin $(\mathrm{g} / \mathrm{dl})=$ total protein $(\mathrm{g} / \mathrm{dl})-$ albumin $(\mathrm{g} / \mathrm{dl})$.Aspartate aminotransferase (ASAT), alanine aminotransferase (ALAT) activities, creatinine, BUN concentrations as well as lipid profile [total cholesterol, triglycerides and high-density lipoprotein cholesterol (HDL-C)] were also determined. All parameters were estimated using Bio Merieux SA kits, France.

The ratio of serum albumin/ globulin was determined. However, ratios of TC/HDL (risk factor 1) and LDL/HDL (risk factor 2) were also calculated after calculation of serum LDL-C (low-density lipoprotein cholesterol) and VLDL (very low density lipoprotein cholesterol) using the Friedwald's ${ }^{(7)}$ and Norbert ${ }^{(8)}$ formulas, respectively as following:

Friedewald's equation:

LDL $(\mathrm{mg} / \mathrm{dl})=\mathrm{TC}-\{\mathrm{HDL}+[\mathrm{TG} / 5]\}$. Norbert equation: $\mathrm{VLDL}=\mathrm{TG} / 5$.

\section{Hormonal assay}

Estimation of serum luteinizing hormone (LH) follicles-stimulating hormone (FSH) and testosterone (T) levels.

They were estimated by using manufacture instructions of kit. All kits used for hormone assay were from Monobind Inc. lake forest CA 92630, USA.

\section{Sperm collection and evaluation}

The rats were sacrificed, and the left caudal epididymis was separated and the total recovered sperm volume during $4 \mathrm{~h}$ of incubation in normal saline (volume $=1 \mathrm{ml}, 35 \sim 37^{\circ} \mathrm{C}$ ) was calculated. The sperm concentration was determined by the conventional method using a hemocytometer chamber for the red blood cell count. The right epididymis was finely minced by anatomical scissors in $1 \mathrm{ml}$ of warmed isotonic saline in a petridish.

The sperm progressive motility (SPM) was estimated by evaluating 4 fields of asperm droplet under a cover-slip on a warm glass slide $\left(35 \sim 37^{\circ} \mathrm{C}\right)$ under light microscopy $(\times 40)$. The sperm vitality was assayed using a conventional procedure of eosin Bnigrosin stain (1.67\% eosin, $10 \%$ nigrosin, and $0.1 \mathrm{M}$ sodium citrate) under $\times 100$ magnification and 100 sperm were counted. All of the sperm evaluation procedures were carried out based on the World Health Organization manual for human sperm analysis with some modifications ${ }^{(9)}$.

\section{Ethical approval}

The study was approved by the Ethics Board of AlAzhar University.

\section{Statistical analysis}

The results were expressed as Mean \pm SEM. Data were analyzed by independent t-test and were performed using the Statistical Package (SPSS) program, version 19.

\section{RESULTS}

\section{Liver functions}

Results of the present study showed nonsignificant change in ALAT and ASAT in the treated groups when compared to control rats (Table 1).

Table 1: Changes in the ALAT and ASAT levels in the control and treated groups

\begin{tabular}{|c|c|c|}
\hline Groups & Control & Fennel oil \\
\hline PLATT(U/L) & $22.5 \pm 0.6$ & $18.5 \pm 0.42$ \\
\% of change & & $-17.7 \%$ \\
\hline ASAT(U/L) & $33.5 \pm 0.5$ & $30.5 \pm 0.56$ \\
\% of change & & $-8.9 \%$ \\
\hline
\end{tabular}

Values represent mean $\pm \mathrm{SE}$ (stander error).

\section{Lipid profile}

Fennel oil induced highly significant decrease $(\mathrm{p}<0.01)$ in TC, TG, LDL, VLDL, LDL/HDL. And significant increase $(\mathrm{p}<0.05)$ in HDL, as compared to control animals (Table 2). 
Table 2: Changes in the lipid profile levels in the control and treated groups

\begin{tabular}{|c|c|c|}
\hline $\begin{array}{ll}\text { Groups } & \text { Parameters } \\
\end{array}$ & Control & Fennel oil \\
\hline $\begin{array}{l}\text { TC(mg/dl) } \\
\% \text { of change }\end{array}$ & $141.3 \pm 0.42$ & $\begin{array}{c}95.0 \pm 0.0001 * * \\
-32.7 \%\end{array}$ \\
\hline $\begin{array}{l}\text { TG(mg/dl) } \\
\text { \% of change }\end{array}$ & $71.5 \pm 1.56$ & $\begin{array}{l}\text { 43.0 } \pm 0.0001 * * \\
-39.8 \%\end{array}$ \\
\hline $\begin{array}{l}\text { HDL(mg/dl) } \\
\text { \% of change }\end{array}$ & $50.33 \pm 0.33$ & $\begin{array}{c}62.7 \pm 0.0001 * * \\
-24.5 \% \\
\end{array}$ \\
\hline $\begin{array}{l}\text { LDL(mg/dl) } \\
\text { \% of change }\end{array}$ & $71.2 \pm 1.27$ & $\begin{array}{c}23.7 \pm 0.0001 * * \\
-66.7 \% \\
\end{array}$ \\
\hline $\begin{array}{l}\text { VLDL(mg/dl) } \\
\% \text { of change }\end{array}$ & $14.30 \pm 0.31$ & $\begin{array}{l}8.6 \pm 0.0001 * * \\
-39.8 \%\end{array}$ \\
\hline $\begin{array}{l}\text { LDL/HDL(mg/dl) } \\
\text { \% of change }\end{array}$ & $1.22 \pm 0.007$ & $\begin{array}{c}0.37 \pm 0.0001 * * \\
-69.6 \% \\
\end{array}$ \\
\hline $\begin{array}{l}\text { TC/HDL(mg/dl) } \\
\% \text { of change }\end{array}$ & $2.47 \pm 0.008$ & $\begin{array}{l}1.51 \pm 0.001 * * \\
-38.8 \%\end{array}$ \\
\hline
\end{tabular}

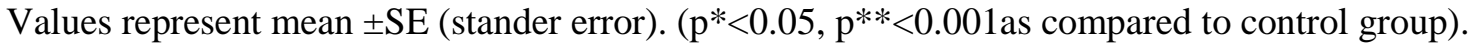

\section{Kidney functions}

The data in table 3 showed no significant changes in urea and serum creatinine in fennel oil group as compared to control group (Table 3).

Table 3: Changes in BUN and creatinine levels in the control and treated groups

\begin{tabular}{|c|c|c|}
\hline Groups Parameters & Control & Fennel oil \\
\hline BUN (mg/dl) & $20.3 \pm 0.2$ & $21.6 \pm 0.4$ \\
\% of change & & $6.4 \%$ \\
\hline Creatinine $(\mathrm{mg} / \mathrm{dl})$ & $0.7 \pm 0.2$ & $0.8 \pm 0.01$ \\
\% of change & & $14.3 \%$ \\
\hline
\end{tabular}

Values represent mean \pm SE (stander error).

Body weight and glucose level

Results of the present study showed non-significant change in body weight in the treated group when compared to control rats and a high significant decrease $(\mathrm{P}<0.01)$ in glucose level in the treated group when compared to control rats (Table 4).

Table 4: Changes \% of body weight and FBS levels in the control and treated groups

\begin{tabular}{|c|c|c|}
\hline Groups & Control & Fennel oil \\
\hline Body weight & & $148.8 \pm 0.4$ \\
\% of change & $137.6 \pm 0.4$ & 15.4 \\
\hline FBS (mg/dl) & & $\mathbf{8 6} \pm 2.7 * *$ \\
\% of change & $94 \pm 2.8$ & $-8.5 \%$ \\
\hline
\end{tabular}






\section{Protein profile}

The present study showed that administration of fennel oil to normal rats showed non-significant change in total protein, albumin, globulin, and albumin/globulin ratio in the treated group when compared to control rats (Table 5).

Table 5: Changes in the total protein, albumin, globulin, albumin/globulin and albumin/globulin levels in the control and treated groups

\begin{tabular}{|c|c|c|}
\hline $\begin{array}{ll}\text { Groups } & \\
\end{array}$ & Control & fennel oil \\
\hline $\begin{array}{l}\text { Total protein }(\mathrm{g} / \mathrm{dl}) \\
\% \text { of change }\end{array}$ & $6.4 \pm 0.11$ & $\begin{array}{l}5.9 \pm 0.2 \\
-23.4 \%\end{array}$ \\
\hline $\begin{array}{l}\text { Albumin }(\mathrm{g} / \mathrm{dl}) \\
\% \text { of change }\end{array}$ & $3.7 \pm 0.11$ & $\begin{array}{l}3.4 \pm 0.1 \\
-10.8 \%\end{array}$ \\
\hline $\begin{array}{c}\text { Globulin (g/dl) } \\
\% \text { of change }\end{array}$ & $2.7 \pm 0.18$ & $\begin{array}{l}1.5 \pm 0.2 \\
-44.4 \%\end{array}$ \\
\hline $\begin{array}{l}\text { Ilbumin/Globulin }(\mathrm{g} / \mathrm{dl}) \\
\% \text { of change }\end{array}$ & $1.3 \pm 0.1$ & $\begin{array}{l}2.2 \pm 0.4 \\
\% 69.2\end{array}$ \\
\hline
\end{tabular}

Values represent mean $\pm \mathrm{SE}$ (stander error).

\section{Hormones}

FSH and testosterone showed highly significant decrease $(\mathrm{p}<0.02)$, while LH showed insignificant change in fennel oil group when compared to control rats(Table 6).

Table 6: Changes in the FSH, LH and testosterone levels in the control and treated groups

\begin{tabular}{|c|c|c|}
\hline Groups Parameters & Control & Fennel oil \\
\hline $\begin{array}{c}\text { FSH(ng/ml) } \\
\text { \% of change }\end{array}$ & $2.9 \pm 0.1$ & $\mathbf{2 . 2 \pm 0 . 1 * *}$ \\
\hline LH(ng/ml) & & $-24.1 \%$ \\
\hline of change & $1.9 \pm 0.1$ & $1.7 \pm 0.1$ \\
Testosterone( $\mu \mathrm{uu} / \mathrm{dl})$ & & $-\mathbf{1 0 . 5 \%}$ \\
\% of change & $3.9 \pm 0.2$ & $\mathbf{2 . 9 \pm 0 . 2 * *}$ \\
\hline
\end{tabular}

Values represent mean $\pm \mathrm{SE}$ (stander error). ( $\mathrm{p}^{*}<0.05, \mathrm{p}^{* *}<0.001$ as compared to control group).

\section{Sperm count}

The data in table 7 showed decreased in sperm count in fennel oil group when compared to control rats.

Table 7: Sperm count in the control and fennel oil group.

\begin{tabular}{|c|c|c|}
\hline Groups Parameters & Control & Fennel oil \\
\hline $\begin{array}{c}\text { Sperm count*10 } \% \text { ml } \\
\% \text { of change }\end{array}$ & $\mathbf{1 0 0 \pm 0 . 0 1}$ & $\mathbf{5 6} \pm 0.01$ \\
\hline
\end{tabular}

\section{DISCUSSION}

In the present study fennel oil lead to decrease in cholesterol, triglycerides and LDL-c levels. Antioxidative properties and radical scavenging activity may be the possible mechanisms by which fennel ameliorated the total lipids, cholesterol, triglycerides and LDL-c ${ }^{(10)}$.Anethole (t-anethole) that is the main compound in all fennel volatile oils possesses significant antioxidant activity. The presence of t-anethole and flavonoids content in fennel might be associated with lowering total lipids, 
cholesterol, triglycerides and LDL-c levels. So fennel is suggested to be a new alternative for clinical management of hyperlipidemic patients ${ }^{(11)}$.

In the present study fennel oil lead to decrease in glucose level. In a study by Parsaeyan ${ }^{(12)}$, he showed marked improvements of hyperglycemia and pathological changes induced by streptozotocin after fennel ingestion, which can prove its effect as antidiabetic in folk medicine. Furthermore, Anitha $e t$ al. ${ }^{(13)}$ suggested that the fennel exhibited the antidiabetic activity by decreasing oxidative stress and preserving pancreatic beta-cell integrity ${ }^{(14)}$.The hypoglycemic effect of fennel might be due to the presence of triterpenes, steroids, saponins and phenolic compounds ${ }^{(\mathbf{1 5})}$.

In the present study, fennel oil lead to decrease in FSH, testosterone and sperm count. Spermatogenesis is stimulated by androgen but inhibited by estrogen and progesterone ${ }^{(16)}$.Anethole is a phytoestrogen found in fennel and has an estrogen like effects, it can decrease blood testosterone level through Sertoli cells that can convert testosteroneto estradiol and secrete inhibin, which suppresses FSH synthesis leading to decline in testosterone level. So, this decline finally causes a decrease in spermatogenesis $^{(17)}$.

In a study by Zondekand Bergmann ${ }^{(18)}$, they found that polyanethol compounds that exist in fennel oil are five times more active than pure anethole. Anethole possesses anti-spermatogenic effects and reduces sperm concentrations in epididymis in adult male albino rats ${ }^{(19)}$. The hormonal inhibition leads to the decrease in sperm count and sperm motility as a result of low androgen levels ${ }^{(20)}$.

\section{REFERENCES}

1-Choi EM,Hwang JK (2004): Antiinflammatory analgesic and antioxidantactivities of the fruit of Foeniculumvulgare.Fitoterapia,75: 557-565.

2-Csupor- Löffler B, Hajdú Z, ZupkóIet al. (2009): Antiproliferative effect of flavonoids and sesquiterpenoids from Achilleamillefoliums.l. on cultured human tumour cell lines. Phytother Res., 23: 672-676.

3- Kooti W, Moradi M, Ali Akbari S et al. (2015): Therapeutic and pharmacological potential of Foeniculumvulgare Mill: a review. J HerbmedPharmacol.,4: 1-9.

4- Dehghani F, Panjehshahin M R, Mirzaee $\mathrm{Z}$ et al.(2005): Effect of Foeniculumvulgare organic extract on blood sex hormones and reproductive tissues of male rats. J ApplAnim Res., 27: 17-20.
5-Friedwald's WT, Levy RI, Fredrickson DS et al. (1999): Estimation of the concentration of low-density lipoprotein cholesterol in plasma, without use of the preparative ultracentrifuge. Clin. Chem., 18:499-502.

6-Norbert WT(1995): Clinical guide to laboratory tests.3rd ed.Saunders W.B. company,Philadephi, 35: 972-972

7-Friedwald'sWT, Levy RI, Fredrickson DSet al. (1999): Estimation of the concentration of low-density lipoprotein cholesterol in plasma, without use of the preparative ultracentrifuge. Clin. Chem., 18:499-502

8-NorbertWT (1995): clinical guide to laboratory tested.3rded.saundersW.B.,company ,philadephi.

9-WHO (2010):WHO laboratory manual for the examination andprocessing of human semen. 5th ed. Geneva, Swittzerland,WHO press, pp: 22-44.

10-Helal EG, Eid FA, Wahsh AM and Ahmed E (2011): Effect of fennel (Foeniculum vulgare) on hyperlipidemic rats. The Egyptian Journal of Hospital Medicine 43: 212 -225 .

11- Birdane FM, Cemek M, Birdane YO et al. (2007): Beneficial effects of FoeniculumVulgare on ethanol-induced acute gastric mucosal injury in rats. World J. Gastroenterol., 13(4): 607-611.

12- Parsaeyan N (2016): The Effect of Foeniculumvulgare (Fennel) Extract on Lipid Profile, Lipid Peroxidation and Liver Enzymes of Diabetic Rat. Iranian Journal of Diabetes \& Obesity (IJDO), 8(1): 24-29.

13- Anitha $\mathrm{T}$, Balakumar $\mathrm{C}$, IlangoKB et al.(2014): Antidiabetic activity of the aqueous extracts of Foeniculumvulgare on streptozotocin-induced diabetic rats. Int J Adv Pharm BiolChem., 3(2): 487-494.

14- El-Dakhakhny M, Mady N, Lembert $\mathrm{N}$ et al.(2002): The hypoglycemic effect of fennel oil is mediated by extrapancreatic actions. Planta Med., 68: 465- 466.

15- Osman NN, Jambi EJandAseri NH (2017):Assessment of antidiabetic and antioxidant activities of Cassia angustifolia and Feoniculumvulgare in diabetic rats. International Journal of Pharmaceutical Research\&Allied Sciences, 6 (2):149-162.

16- Albert-PuIeo $M$ (1980):Fennei and anise as estrogenicagents. J. Ethnopharmacol., 2: 337-344.

17- Dohle GR, Smit M,Weber RF (2003): Androgensand male fertility. World J.Urol., 21: 342-345.

18- ZondekB,Bergmann E (1938): Phenol methyl ethers as oestrogenic agents. Biochemical Journal,32 : 641 -645.

19- Bhuvaneswari G (1987): Effect of anethole on testis and epididymis of rats.

https://pdfs.semanticscholar.org/d9df/d777218dc60885f4c9 5044981c4824d48e47.pdf

20- Noori ML (2017): Physiological,Hormonal and Histological Effects of Fennel seeds (Foeniculumvulgare)on Thyroid and Testes in Male Rats. International Journal of ChemTech Research, 10: 373 387. 